\title{
Implementation and progress of clinical pharmacy in the rational medication use in a large tertiary hospital
}

\author{
Implantação e evolução da farmácia clínica no uso racional de medicamentos em hospital \\ terciário de grande porte
}

Fábio Teixeira Ferracini ${ }^{1}$, Silvana Maria de Almeida ${ }^{1}$, Juliana Locatelli ${ }^{1}$, Sandra Petriccione ${ }^{1}$, Celina Setsuko Haga ${ }^{1}$

\begin{abstract}
Objective: To show developments and contributions of a clinical pharmacy service in safety and rational use of medications in a large tertiary hospital. Methods: Clinical pharmacists were responsible for all issues using medications at the hospital. In the beginning this professional was responsible for analyzing medical prescriptions, horizontal visits, and to set up protocols. Afterwards, other activities were designated such as monitoring for drug safety, participating in committees and managed routines. If problems were found, the pharmacist reported them for the physician and, after intervention, registered the management on the prescription or in medical records. The data collected were presented as reports to medical managers. Results: There was an increase of clinical pharmacist employed in 2010, reaching 22 individuals. Interventions types also increased from 1,706 in 2003 to 30,727 in 2010. The adhesion observed in medical team in 2003 was $93.4 \%$, reaching $99.5 \%$ of adhesion in 2010 . Conclusion: Clinical pharmacy service shows a positive impact when it comes to performed interventions. It also promotes a rational use of medicines and increase patient safety. Pharmacists were included and their importance confirmed within the multidisciplinary team and in the process of patient safety.
\end{abstract}

Keywords: Safety; Drug utilization; Pharmacy service, hospital

\section{RESUMO}

Objetivo: Demonstrar o desenvolvimento e a contribuição da farmácia clínica no uso seguro e racional de medicamentos em hospital terciário de grande porte. Métodos: 0 trabalho envolveu a participação do farmacêutico clínico em todas as questões relacionadas ao uso de medicamentos no hospital. No início, estava relacionado à análise da prescrição médica, visita horizontal e implantação de protocolos. Posteriormente, outras atividades foram incorporadas como: farmacovigilância, participação em comissões e rotinas gerenciadas. Após a identificação do problema relacionado ao medicamento, 0 farmacêutico contatava o médico e, após a intervenção, registrava a conduta na prescrição e ou no prontuário do paciente. Os dados eram apresentados em forma de relatórios e divulgados para a gerência médica. Resultados: Houve aumento no número de farmacêuticos clínicos, chegando a 22 em 2010. Houve também aumento dos tipos e de número de intervenções realizadas (de 1.706 em 2003 para 30.727 em 2010) e observamos $93,4 \%$ de adesão pela equipe médica em 2003, chegando a 99,5\% em 2010. Conclusões: A farmácia clínica demonstrou impacto positivo em relação ao número de intervenções realizadas, promovendo uso racional de medicamentos e aumento da segurança do paciente. 0 farmacêutico foi inserido e garantiu seu espaço junto à equipe multidisciplinar e no processo de segurança do paciente dentro da instituição.

Descritores: Segurança; Uso de medicamentos; Serviço de farmácia hospitalar

\section{INTRODUCTION}

Clinical pharmacy was characterized in 1960s in the United States as dealing with activities that maximize therapy, lower risks and costs, and also promote the safety and rational use of medication.

The role of the clinical pharmacist is to promote health, to prevent and monitor adverse events, contributing to the prescription of medicines to achieve positive clinical results, to improve the consumer's quality of life and to guarantee the cost-effectiveness of therapy ${ }^{(1,2)}$.

Several studies relate the positive impact of the pharmacist participation in the prescription of antimicrobial agents, considering its misuse has a critical role in the selection of resistant microorganisms and the medication risk of super-infections, besides the involved costs. One of these studies reported that the assigned pharmacist to the Intensive Care Unit (ICU)

\footnotetext{
Study carried out at Hospital Albert Einstein - HIAE, São Paulo (SP), Brazil.

'Hospital Israelita Albert Einstein - HIAE, São Paulo (SP), Brazil.

Corresponding author: Silvana Maria de Almeida - Avenida Albert Einstein, 627 - Morumbi - CEP 05651-901 - São Paulo (SP), Brazil - Tel.: (11) 2151-2249 - E-mail: silvanama@einstein.br

Received on: Jun 13, 2011 - Accepted on: Nov 8, 2011

Conflict of interest: none
} 
reduced in $66 \%$ the avoidable adverse events. Adverse events are associated to an increase in the length of stay in 1.9 days and to death risk $^{(3,4)}$.

Another study recorded 844 interventions in 201 transplanted patients, $28.4 \%$ being associated to the medication indication, $26.6 \%$ to high dose and $18.1 \%$ to subdose ${ }^{(5)}$.

According to the Institute of Medicine (IOM) in the United States around 100,000 deaths happen yearly due to errors in patient care, from this total 7,000 related to medication, which corresponds to a cost of US\$77 billion/year ${ }^{(6)}$.

Therefore, the presence of the clinical pharmacist in hospitals, working with the medical team, may increase the quality and safety of patient care as well as the management of resources.

\section{OBJECTIVE}

To show quantitative and qualitative evolution of clinical pharmacy in a large tertiary hospital.

\section{METHODS}

This is prospective study done at Hospital Israelita Albert Einstein having approximately 600 beds distributed in 15 inpatient units, including three ICUs (adult, pediatric and neonatal) from 2003 to 2010.

The project of the clinical pharmacy started in 1999 to address the recommendations of the Joint Commission International in order to receive its accreditation for the hospital. We identified specific actions for the clinical pharmacy and at this point the hospital assigned a clinical pharmacist to the ICUs.

During the activities this professional was integrated to the team in all issues involving the patient. In the beginning, the pharmacist's dutieswere related tomedical prescriptions, horizontal visits with the medical team and to implement some protocols, such as antimicrobial agent prophylaxis in surgery, follow-up of antimicrobial agents consumption, and drug interaction. However, along the evolution of the process new duties were assigned to this professional, and new areas of the hospital became interested in having a pharmacist participating in their activities.

Since 2003 the process to enlarge the clinical pharmacy participation started for all hospital areas and in 2006, pharmacists were involved in the management of routines in the institution besides more advanced clinical activities.

The first phase of the project in 2003 constituted the implementation phase with systematic data collection, and from these data the planning for the expansion of the work and the assistance to other inpatient units of the hospital was implemented.
We evaluated the number of pharmacists involved in the clinical pharmacy, the number of interventions, medical acceptance and the number of patients seen daily.

Interventions were classified as: oral administration, frequency, dose, compatibility, dilution, description/liability, interaction, allergy, infusion time, indication, pharmacosurveillance/reaction, adverse drug reaction, reconciliation, medication versus catheter, schedule, anticoagulants, opioids versus laxative, and hypoglycemic agents.

The following adherence adopted in 2006 by pharmacists and physicians to the managed routines was also considered: protocols for the use of human albumin, in which verification was done on albumin indication according to $\mathrm{RDC} \mathrm{n}^{\circ} 115$ of May 10th, 2004; antibiotic prophylaxis in surgery considering the adherence to antibiotic withdrawal within 48 hours, and adequate antibiotic withdrawal up to 14 days; monitoring drugs of low therapeutic index; considering the inclusion criteria for serum monitoring and follow-up use of drugs like vancomycin, phenytoin, carbamazepine, valproic acid, fenobarbital besides digoxin and caffeine in the neonatal unit.

The intervention process of the pharmacist was to analyze the medical prescription and if any problem related to medication was found the situation was reported to the physicians and the case discussed with them. If the physician agreed (adherence), the pharmacist changed the management and recorded the adequacies discussed on the medical prescription or on the patient's medical record. After that, all interventions made were documented in a daily report (duty hours).

Information was obtained from the data recorded in the daily reports (duty hours) on the interventions made during duty hours as well as detailed descriptions of the type of management and resolution as accepted or not by the physician who prescribed it.

\section{RESULTS}

Since 2003, a total of 10 clinical pharmacists delivered assistance to adult, pediatric and oncology ICUs. Other inpatient units were assisted partially with one pharmacist for each two units.

After the systematization and report of data in 2003 (January to December) there was a financial aid to expand the work to the other clinical units.

After presenting the increase in interventions in $51.1 \%$ between 2003 and 2004, we could justify the increase in the pharmacy workforce that in 2005 reached 16 professionals, which represented an increase of $60 \%$ in our work force. It enabled us to assist hospital units with one pharmacist placed in each inpatient unit.

In addition to the increase in the workforce, there was an increase of types of interventions made by the pharmacists (from 7 to 19) (Tables 1 and 2). 
Table 1. Distribution of results related to the participation of the clinical pharmacist in the hospital

\begin{tabular}{|c|c|c|c|c|c|c|c|c|}
\hline Year & $\begin{array}{c}\text { Number of } \\
\text { interventions }\end{array}$ & Increase $(\%)^{*}$ & $\begin{array}{c}\text { Types of } \\
\text { interventions }\end{array}$ & Increase $(\%)^{*}$ & $\begin{array}{c}\text { Number of } \\
\text { pharmacists }\end{array}$ & Increase $(\%)^{*}$ & $\begin{array}{c}\text { Intervention/ } \\
\text { pharmacist }\end{array}$ & Patient/day \\
\hline 2003 & 1,706 & - & 7 & - & 10 & - & 171 & 124,736 \\
\hline 2004 & 2,577 & 51.1 & 11 & 57.1 & 10 & 0.0 & 258 & 137,443 \\
\hline 2005 & 6,399 & 148.3 & 12 & 9.1 & 16 & 60.0 & 400 & 141,941 \\
\hline 2006 & 16,971 & 165.2 & 15 & 25.0 & 16 & 0.0 & 1061 & 140,344 \\
\hline 2007 & 22,357 & 31.7 & 16 & 6.7 & 16 & 0.0 & 1397 & 138,799 \\
\hline 2008 & 25,369 & 13.5 & 17 & 6.3 & 20 & 25.0 & 1268 & 150,045 \\
\hline 2009 & 25,655 & 1.1 & 19 & 11.8 & 22 & 10.0 & 1166 & 159,740 \\
\hline 2010 & 30,727 & 19.8 & 19 & 0.0 & 22 & 0.0 & 1397 & 183,045 \\
\hline
\end{tabular}

* Percentage of increase compared with the previous year.

Table 2. Evolution of interventions

\begin{tabular}{|c|c|c|c|c|c|c|c|c|}
\hline Administration route & 11 & 10 & 10 & 12 & 5 & 5 & 4 & 4 \\
\hline Dosage & 45 & 42 & 31 & 25 & 21 & 21 & 23 & 25 \\
\hline Compatibility & 7 & 6 & 9 & 14 & 12 & 16 & 16 & 8 \\
\hline Interaction & 1 & 8 & 10 & 6 & 15 & 17 & 15 & 19 \\
\hline Allergy & - & 1 & 1 & 1 & 1 & 1 & 1 & 1 \\
\hline Infusion time & - & 2 & 3 & 4 & 5 & 5 & 4 & 1 \\
\hline Indication & - & 3 & 13 & 10 & 3 & 4 & 3 & 4 \\
\hline Schedule & - & - & - & - & - & 3 & 3 & 6 \\
\hline Anticoagulants & - & - & - & - & - & 2 & 2 & 2 \\
\hline Opioids versus laxative & - & - & - & - & - & - & 3 & 1 \\
\hline Hypoglycemic & - & - & - & - & - & - & - & 4 \\
\hline
\end{tabular}

We also observed an increase in pharmaceutical interventions on medical prescription (from 1,706 in 2003 to 30,727 in 2010) (Table 1 and Figure 1).

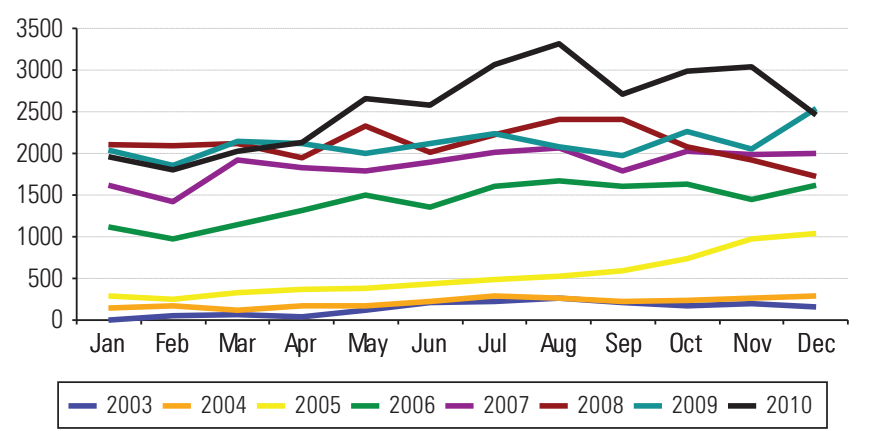

Figure 1. Evolution of pharmaceutical intervention between 2003 and 2010
An increase from 0.014 to 0.168 was observed in the period of the study towards the number of interventions for patient/day in the hospital (Table 3).

Table 3. Number of pharmaceutical interventions by patient/day in the hospital

\begin{tabular}{cccc}
\hline Year & $\begin{array}{c}\text { Number of } \\
\text { interventions }\end{array}$ & Patient/day & $\begin{array}{c}\text { Number of interventions- } \\
\text { patient/day }\end{array}$ \\
\hline 2003 & 1,706 & 124,736 & 0.014 \\
2004 & 2,577 & 137,443 & 0.019 \\
2005 & 6,399 & 141,941 & 0.045 \\
2006 & 16,971 & 140,344 & 0.121 \\
2007 & 22,357 & 138,799 & 0.161 \\
2008 & 25,369 & 150,045 & 0.169 \\
2009 & 25,655 & 159,740 & 0.161 \\
2010 & 30,727 & 183,045 & 0.168 \\
\hline
\end{tabular}


As for interventions made by pharmacists, that is, for the problems identified in medical prescriptions in which pharmacists discussed alterations with the physicians, their adherence was $93.4 \%$ in 2003 , and in 2010 this number reached $99.5 \%$ (Figure 2).

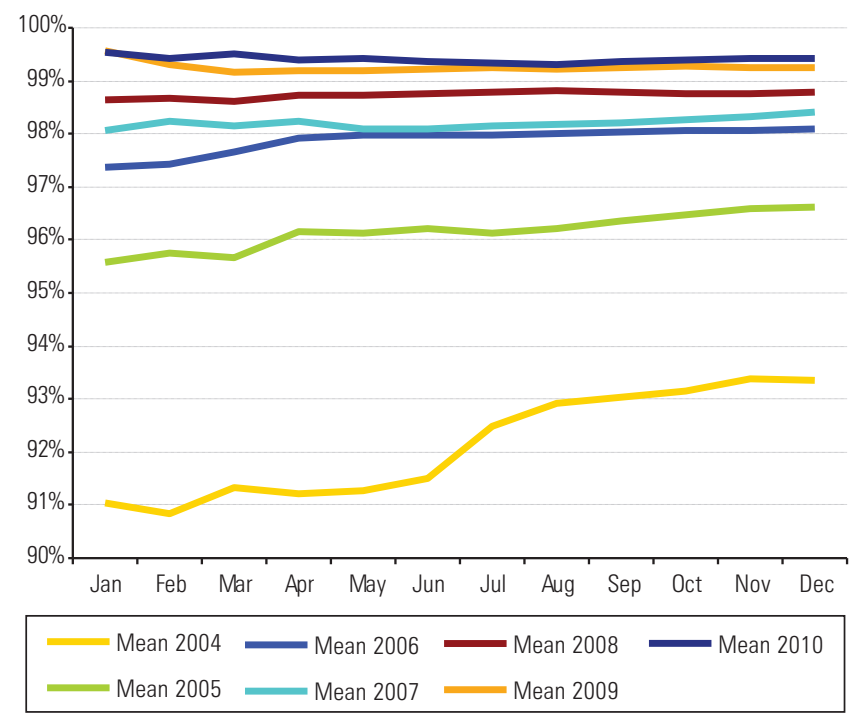

Figure 2. Evolution of physicians' adherence to pharmaceutical interventions

For the follow-up of managed routines since 2006 there was an increase in physician's adherence to all the routines, being $30 \%$ for the adequate use of human albumin, $12 \%$ for the routine of antibiotic prophylaxis in surgery, $5.2 \%$ for antimicrobial agent therapy, and $2.6 \%$ for drugs of low therapeutic index (Table 4).

Table 4. Physicians' adherence to managed routines

\begin{tabular}{ccccc}
\hline Period & $\begin{array}{c}\text { Human } \\
\text { albumin (\%) }\end{array}$ & $\begin{array}{c}\text { Antimicrobial agent } \\
\text { prophylaxis in } \\
\text { surgery (\%) }\end{array}$ & $\begin{array}{c}\text { Antibiotic } \\
\text { prophylaxis } \\
(\%)\end{array}$ & $\begin{array}{c}\text { Low } \\
\text { therapeutic } \\
\text { index drugs } \\
\text { (\%) }\end{array}$ \\
\hline 2006 & 68 & 61 & 90 & 96 \\
2007 & 74 & 67 & 95 & 98 \\
2008 & 87 & 68 & 97 & 95 \\
2009 & 97 & 72 & 94 & 98 \\
2010 & 98 & 73 & 95 & 98 \\
\hline
\end{tabular}

\section{DISCUSSION}

Improving safety in medication use is associated to secure processes, strategies to prevent errors and adverse events, reducing its consequences. The pharmacist participation promotes safety by reducting avoidable reactions, decreasing the length of hospital stay, mortality and costs ${ }^{(7-11)}$.
Increased patient safety in hospitals is associated to increased number of clinical pharmacists and clinical pharmacy services provided for these patients. One of the most effective ways to reduce medication errors in hospitals is to have clinical pharmacists and to enlarge their work ${ }^{(12)}$.

We observed in this study that participation and enlargement of the clinical pharmacy in our hospital increased the number and types of interventions made by pharmacists in medical prescriptions between 2003 and 2010, which may represent a positive impact in patient safety.

Our findings are in agreement with other studies on pharmaceutical interventions that reported adherence by the medical team in most interventions (from $92.8 \%$ to $99 \%)^{(12-14)}$. In our service an adherence of $99.5 \%$ in 2010 was found.

Cost-benefits of the clinical pharmacy may vary depending on the type of institution, the number of interventions made, the amount of monitored beds, and the pharmaceutical service provided. The clinical pharmacist presence has demonstrated a significant cost-effectiveness advantage ${ }^{(15-17)}$. A prospective and randomized study assessed interventions made by pharmacists at 1,200 university hospitals, being observed a decrease in $41 \%$ in costs in those where interventions were made when compared to a control group ${ }^{(18,19)}$.

It was also shown that new types of interventions have been included as time elapsed and that they also became more specific, for example, the follow-up of patients using anticoagulants, hypoglycemic agents and opioids, which showed involvement of the pharmacist in clinical activities and helped to identify new areas of acting.

Therefore, it is important to highlight the need to storage, analyze data, and follow-up the results of this work not only to address the standards stated by the Joint Commission International, but also to support the clinical and administrative personnel in decision making. Besides it supports sharing information with other services (benchmarking).

\section{CONCLUSION}

To implement and enlarge the clinical pharmacy represented a positive impact to the number of interventions by the clinical pharmacist during the period considered. It also enabled to promote the rational use of medication, to increase the patient safety, and to contribute for cost reduction related to the medical prescription.

In our institution pharmacists were included gradually and effectively, within the multidisciplinary team and in the process of patient safety having their importance confirmed in the Institution. 


\section{REFERENCES}

1. Holland RW, Nimmo CM. Transitions, part 1: beyond pharmaceutical care. Am J Health Syst Pharm. 1999;56(17):1758-64.

2. American Society of Hospital Pharmacists. ASHP guidelines on documenting pharmaceutical care in patient medical records. Am J Health Syst Pharm. 2003;60(7):705-7.

3. Brilli RJ, Spevetz A, Branson RD, Campbell GM, Cohen H, Dasta JF, et al. Critical care delivery in the intensive care unit: defining clinical roles and the best practice model. Crit Care Med. 2001;29(10):2007-19.

4. Chuang LC, Sutton JD, Henderson GT. Impact of a clinical pharmacist on cost saving and cost avoidance in drug therapy in an intensive care unit. Hosp Pharm. 1994;29(3):215-8, 221.

5. Manley HJ, Carroll CA. The clinical and economic impact of pharmaceutical care in end-stage renal disease patients. Semin Dial. 2002;15(1):45-9.

6. Kohn LT, Corrigan JM, Donaldson MS. Errors in health care: a leading cause of death and injury In: Kohn LT, Corrigan JM, Donaldson MS. To err is human: building a safer health system. Washington: IOM National Academy Press; 1999. p.25-48.

7. McCreadie SR, Callahan BL, Collins CD, Walker PC. Improving information flow and documentation for clinical pharmacy services. Am J Health Syst Pharm. 2004;61(1):46-9.

8. Montazeri M, Cook DJ. Impact of a clinical pharmacist in a multidisciplinary intensive care unit. Crit Care Med. 1994;22(6):1044-8.

9. Scarsi KK, Fotis MA, Noskin GA. Pharmacist participation in medical rounds reduces medication errors. Am J Health Syst Pharm. 2002;59(21):2089-92.
10. Moyen E, Camiré E, Stelfox HT. Clinical review: medication errors in critical care. Crit Care. 2008;12(2):208.

11. Langebrake $\mathrm{C}$, Hilgarth $\mathrm{H}$. Clinical pharmacists interventions in a German university hospital. Pharm World Sci. 2010;32(2):194-9.

12. Bond CA, Raehl CL, Franke T. Clinical pharmacy services, hospital pharmacy staffing, and medication erros in the United States hospitals. Pharmacoterapy. 2002;22(2).

13. Saokaew S, Maphanta S, Thangsomboon P. Impact of pharmacist's interventions on cost of drug therapy in intensive care unit. Pharm Pract. 2009;7(2):81-7.

14. Kopp BJ, Mrsan M, Erstad BL, Duby JJ. Cost implications of and potential adverse events prevented by interventions of a critical care pharmacist. Am J Health Syst Pharm. 2007;64(23):2483-7.

15. Haig GM, Kiser LA. Effect of pharmacist participation on a medical team on costs, charges, and length of stay. Am J Hosp Pharm. 1991;48(7):1457-62.

16. Boyko WL Jr, Yurkowski PJ, Ivey MF, Armitstead JA, Roberts BL. Pharmacist influence on economic and morbidity outcomes in a tertiary care teaching hospital. Am J Health Syst Pharm. 1997;54(14):1591-5.

17. Borges-Filho WM, Almeida SM, Ferracini FT, Fernandes Junior CJ. Contribuição da farmácia na prescrição e uso de albumina humana em um hospital de grande porte. einstein. 2010;8(2 Pt 1):215-20.

18. McMullin ST, Hennenfent JA, Ritchie DJ, Huey WY, Lonergan TP, Schaiff RA, et al. A prospective, randomized trial to assess the cost impact of pharmacistinitiated interventions. Arch Intern Med. 1999;159(19):2306-9.

19. Bond CA, Raehl CL, Franke T. Clinical pharmacy services, pharmacist staffing, and drug costs in United States hospitals. Pharmacotherapy. 1999;19(12):1354-62. 